\title{
EKSPLORASI THINK PAIR SHARE SEBAGAI MODEL DALAM PEMBELAJARAN TEMATIK TERPADU DI SEKOLAH DASAR
}

\author{
Mutiaramses $^{1}$, Firman Firman ${ }^{2}$, Desyandri ${ }^{3}$ \\ 1,2,3PENDAS FIP Universitas Negeri Padang \\ 1mutiaramses3398@gmail.com, 2firman@konselor.org, ${ }^{3}$ desyandri@fip.unp.ac.id
}

\begin{abstract}
The research aims to explore or analyze the effectiveness of implementing the think pair share model in integrated thematic learning in elementary schools. The approach used is qualitative with the type of research that is literature studies. Where researchers analyzed a number of journals and articles from relevant previous research. The data was collected through online traces by searching for journals and articles through google schoolar and j-store. The results of the analysis of various journals found show that the think pair share model is effective in using integrated thematic learning. The effectiveness can be seen from the significant increase in learning outcomes and motivation of students in the two cycles.
\end{abstract}

Keywords: Integrated thematic, Learning Outcomes, Think Pair Share

\section{ABSTRAK}

Penelitian bertujuan untuk mengeksplorasi atau menganalisis keefektifan penerapan model think pair share dalam pembelajaran tematik terpadu di sekolah dasar. Pendekatan yang digunakan adalah kualitatif dengan jenis penelitian yang bersifat studi literatur. Dimana peneliti menganalisis sejumlah jurnal maupun artikel dari penelitian terdahulu yang relevan. Pengumpulan data dilakukan melalui jejak online dengan mencari jurnal dan artikel melalui google schoolar dan j-store. Hasil analisis dari berbagai jurnal yang ditemukan menunjukkan bahwa model think pair share efektif digunakan dalam pembelajaran tematik terpadu. Keefektifan dapat dilihat dari peningkatan hasil dan motivasi belajar peserta didik yang signifikan dalam dua siklusnya.

Kata-kata kunci: tematik terpadu, hasil belajar, think pair share

\section{A. Pendahuluan}

Kurikulum di Indonesia sudah beberapa kali mengalami penyempurnaan. Saat ini berada pada kurikulum 2013 yang lebih dikenal dengan K-13. Hadirnya Kurikulum 2013 menjadi salah satu upaya pemerintah meningkatkan pendidikan

di Indonesia. Kurikulum 2013 berisikan kompetensi dan Karakter dengan hasil penggabungan dari beberapa kebijakan kurikulum sebelumnya (Avelina \& Ria : 2020). Implementasi dari kurikulum 2013 berupa pembelajaran tematik terpadu di 
jenjang sekolah dasar. Pembelajaran pada kurikulum 2013 berpusat pada tematik terpadu dimana tidak adanya pemisah antar mata pelajaran. Seluruh mata pelajaran disatukan atau dipadukan dalam satu tema yang disebut tematik terpadu dengan menekankan penilaian utama berada pada penilaian karakter atau sikap disamping penilaian pengetahuan dan keterampilan (Ichsan Anshory \& Setiya Yunus : 2017). Realisasi tematik terpadu yang sesuai dengan tuntutan kurikulum 2013 mengalami beberapa hambatan dengan karakteristik sekolah yang berbedabeda dan tidak meratanya sosialisasi dalam penerapannya. Sehingga berdampak buruk pada proses, motivasi dan hasil belajar siswa. Beberapa kesulitan guru dalam mengajar dengan melaksanakan pembelajaran tematik terpadu yang peneliti temukan dari berbagai literatur berupa jurnal dan artikel diantaranya : guru masih belum bisa terlepas dari dominasi metode ceramah, peserta didik kurang aktif sehingga pembelajaran berlangsung dengan monoton (Firman \& Nuri Hayatul : 2019). Sejalan dengan temuan (Ahmad Muzaki : 2014) bahwa metode diskusi dengan berbagai model yang ada minim diterapkan dan kerja kelompok kurang diarahkan. Selanjutnya peserta didik cenderung kurang termotivasi karena pembelajaran yang berlangsung masih berpusat pada guru. Sedangkan karakteristik tematik terpadu yang sebenarnya adalah pembelajaran berpusat pada peserta didik dan guru hanya sebagai fasilitator dalam pembelajaran. Artinya guru memantau pembelajaran yang berlangsung tanpa mendominasi dalam proses pembelajaran, jika peserta didik mengalami kesulitan maka disitulah peran guru untuk memberikan penjelasan. Disisi lain guru juga memberikan ringkasan materi dan kesimpulan, yang didapat secara bersama dengan peserta didik. Dari berbagai permasalahan tersebut, tentu saja berdampak pada rendahnya hasil belajar dan kurangnya motivasi belajar peserta didik. Sehingga beberapa literatur baik jurnal maupun artikel mensiasati permasalahan - permasalahan tersebut dengan memilih salah satu model pembelajaran yang dirasa mampu menjadi solusi dalam pembelajaran tematik terpadu. Model pembelajaran tersebut adalah model kelompok yang dikenal dengan think 
pair share. Model ini dipilih berdasarkan beberapa pertimbangan yaitu dengan melihat kelebihan dan kesesuaiannya dengan karakteristik peserta didik dalam pembelajaran tematik terpadu (Fitri Meiharty : 2018).

Menurut Lie (2008), think pair share merupakan gaya belajar yang memberi kesempatan peserta didik untuk bekerja sendiri dan bekerjasama dengan orang lain. Artinya peserta didik tertantang untuk bisa bekerja dalam kelompok dan memacu keaktifan dalam belajar. Model ini juga dapat mengembangkan cara berpikir peserta didik menjadi lebih kritis sehingga bisa mengemukakan ide, gagasan, dan pendapat dengan baik (Dian Septi : 2014). Menurut Frank Layman dalam Riffa Fahrullisa et all (2018), TPS memiliki cara efektif untuk membuat variasi suasana pola diskusi kelas, dimana prosedur yang digunakan dapat memberikan lebih banyak waktu berfikir untuk merespon dan saling membantu antar peserta didik. Tujuan akhir dari diterapkannya model think pair share dalam pembelajaran tematik terpadu adalah meningkatkan hasil belajar dan motivasi belajar peserta didik. Di sisi lain, penelitian ini juga bertujuan untuk menggali dan mengeksplorasi

sejauhmana keefektifan model think pair share dalam pelaksanaan pembelajaran tematik terpadu.

\section{B. Metode Penelitian}

Pendekatan kualitatif dipilih dalam penelitian ini dengan desain penelitian bersifat studi literatur yang menggunakan berbagai sumber seperti jurnal, artikel dan sumber lainnya. Menurut Basrowi dan Suwandi dalam Avelina Meita et all (2008) penelitian kualitatif bertujuan untuk mendapatkan pemahaman yang sifatnya umum terhadap kenyataan sosial dari perspektif partisipan. Data dikumpulkan dengan jejak digital pada google schoolar dan j-store. Dari berbagai jurnal yang peneliti pilih dalam eksplorasi model think pair share ini ditemukan beragam jumlah subjek dan lokasi penelitian, diantaranya : 61 peserta didik kelas V SD Negeri 03 Pedurungan Kecamatan Taman Kabupaten Pemalang, peserta didik kelas IV SDN Jeruk I Surabaya, 41 peserta didik Kelas IV MI Terpadu Muhammadiyah Sukarame Bandar Lampung tahun ajaran 2016/2017, peserta didik kelas IV SDN 09 Surau Gadang Siteba Kota Padang, 22 
peserta didik SD Inpres Mangga Dua Kabupaten Merauke, dan peserta didik kelas IV SDN Margomulyo 02 Blitar. Adapun Teknik pengumpulan data yang digunakan adalah observasi dengan alat pengumpulan data berupa lembar pengamatan, wawancara dengan paparan hasil wawancara, penyebaran angket, dan tes berupa sola-soal yang terkait.

\section{C.Hasil Penelitian dan Pembahasan}

Sejumlah jurnal dan artikel dianalisis untuk mengetahui keefektifan model think pair share dalam meningkatkan hasil dan motivasi belajar peserta didik. Berikut beberapa hasil penelitian yang menunjukkan indikasi bahwa model think pair share layak dan efektif dilaksanakan dalam pemebelajaran tematik terpadu di sekolah dasar.

Tabel. 1 Hasil Eksplorasi Model Think Pair Share.

\begin{tabular}{|c|c|c|c|}
\hline Nama Peneliti & $\begin{array}{c}\text { Tahu } \\
\mathrm{n}\end{array}$ & $\begin{array}{c}\text { Siklus } \\
1\end{array}$ & $\begin{array}{c}\text { Siklus } \\
\text { II }\end{array}$ \\
\hline $\begin{array}{ll}\text { 1. } & \text { Rama } \\
\text { Dania } \\
\text { 2. Elfia } \\
\text { Sukma }\end{array}$ & 2020 & $\begin{array}{c}73,65 \\
\%\end{array}$ & 84,85 \\
\hline $\begin{array}{ll}\text { 1. } & \text { Desi } \\
\text { Indriyani } \\
\text { 2. Desyandr } \\
\text { 3. Yanti Fitria }\end{array}$ & 2019 & $\begin{array}{c}75,83 \\
\%\end{array}$ & $\begin{array}{c}86,67 \\
\%\end{array}$ \\
\hline
\end{tabular}

\begin{tabular}{|c|c|c|c|}
\hline Fitri Meiharty & 2018 & $\begin{array}{c}73,26 \\
\%\end{array}$ & $\begin{array}{c}88,33 \\
\%\end{array}$ \\
\hline Rusdial Marta & 2017 & $65 \%$ & $85 \%$ \\
\hline $\begin{array}{ll}\text { 1. Yonarliant } \\
\text { 2. Tembang } \\
\text { 3. Sulton } \\
\text { Suharjo }\end{array}$ & 2017 & $\begin{array}{c}74,91 \\
\%\end{array}$ & $\begin{array}{c}87,27 \\
\%\end{array}$ \\
\hline $\begin{array}{ll}\text { 1. } & \text { Erika } \\
\text { Puspitasar } \\
\text { 2. Punaji } \\
\text { Setyosari } \\
\text { 3. Ach. } \\
\text { Amirudin }\end{array}$ & 2016 & $14 \%$ & $18 \%$ \\
\hline $\begin{array}{ll}\text { 1. } & \text { Dino } \\
& \text { Sugiarto } \\
\text { 2. } & \text { Puji } \\
& \text { Sumarson } \\
& 0\end{array}$ & 2014 & $74 \%$ & $80 \%$ \\
\hline $\begin{array}{l}\text { Anita Puji } \\
\text { Lestari }\end{array}$ & 2013 & 58,25 & 74,64 \\
\hline $\begin{array}{ll}\text { 1. } & \text { Febrian } \\
\text { Widya } \\
\text { 2. Kusuma } \\
\text { Mimin } \\
\text { 3. Nur Aisyah }\end{array}$ & 2012 & $\begin{array}{c}75,42 \\
\%\end{array}$ & $\begin{array}{c}91,75 \\
\%\end{array}$ \\
\hline
\end{tabular}

Dari berbagai hasil penelitian yang peneliti peroleh dalam berbagai jurnal tentang peningkatan hasil dan motivasi belajar peserta didik menggunakan model think pair share sudah bisa dikatakan bahwa model think pair share efektif diterapkan. Keefektifan model ini diindikasikan dengan angka atau persenan peningkatan hasil belajar dan motivasi peserta didik pada siklus I dan siklus II, yang rata-rata menunjukkan peningkatan yang signifikan. 
Peningkatan hasil dan motivasi peserta didik didasarkan pada implementasi model yang sesuai dengan langkah-langkahnya dan kelebihan yang dimiliki oleh think pair share. Menurut Erika Puspita Sari (2018) , tahapan atau langkah think pair share, yaitu berpikir (think), berpasangan (pair), dan berbagi (share). Sejalan dengan yang dikemukakan Riffa Fahrullisa et all (2018), think pair share memiliki tiga tahapan atau langkah pembelajaran yaitu: Think (berpikir), Pair (berpasangan), share (berbagi). Pada tahapan think guru menyampaikan suatu pertanyaan atau permasalahan kemudian guru meminta peserta didik memikirkan secara individu tentang permasalahan yaang disampaikan. Sedangkan pada tahap pair, peserta didik mendiskusikan dengan pasangannya apa yang sudah mereka pikirkan pada tahap think. Selanjutnya pada tahap share meminta peserta didik untuk menyampaikan atau mengkomunikasikan hasil dari diskusi mereka dengan pasangan lainnya di depan kelas. Sedangkan Fitri Meiharty (2018), mengemukakan bahwa ada 6 langkah pelaksanaan pembelajaran kooperatif yaitu: (1) tahap menyampaikan tujuan pembelajaran dan motivasi siswa, (2) menyajikan informasi,

tahap mengorganisasikan siswa dalam kelompok belajar, (4) membimbing kelompok bekerja dan belajar, (5) evaluasi, memberikan Penghargaan kelompok. Berdasarkan pendapat - pendapat tersebut, dapat diartikan bahwa langkah inti dari model think pair share yang umum digunakan adalah peserta didik berpikir individu terlebih dahulu terkait permasalahan yang diberikan, kemudian guru membentuk kelompok berpasangan, lalu peserta didik berdiskusi dalam kelompok, dan mereka membagikan hasil diskusi sehingga pada akhirnya kelompok terbaik mendapat penghargaan dari guru. Think pair share melatih pola pikir peserta didik menjadi lebih kritis dan memupuk sikap kerjasamanya serta rasa tanggung jawab. Sejalan dengan pendapat El Surraya, et all (2014) bahwa dalam pembelajaran TPS peserta didik belajar bersama sebagai suatu tim dalam menyelesaikan tugas-tugas kelompok untuk mencapai tujuan bersama, sehingga setiap anggota kelompok atau setiap pasangan memiliki tanggung jawab yang sama untuk keberhasilan kelompoknya. Menurut 
Lie dalam Tri Ratna Rahayu, et all (2017) Kelebihan model TPS ini diantaranya : (1) meningkatkan partisipasi siswa dalam pembelajaran; (2) cocok digunakan untuk tugas yang sederhana; (3) memberikan lebih kesempatan untuk kontribusi masingmasing anggota kelompok; interaksi antar pasangan lebih mudah; (5) lebih mudah dan cepat membentuk kelompoknya. Disamping memiliki begitu banyak kelebihan, model pembelajaran think pair share juga tidak lepas dari kekurangan. kekurangannya yaitu: (1) lebih banyak kelompok yang akan lapor dan perlu dimonitor; (2) lebih sedikit ide yang muncul; (3) jika ada masalah tidak ada penengah dan kelompok lebih banyak karena anggota dalam satu kelompok hanya 2 orang.

\section{E. Kesimpulan}

Berdasarkan penelitian dengan pendekatan kualitatif yang bersifat studi literatur yang telah peneliti lakukan pada 25 jurnal relevan, dapat disimpulkan bahwa model pembelajaran think pair share bisa meningkatkan hasil dan motivasi belajar peserta didik dalam pembelajaran tematik terpadu di sekolah dasar. Keberhasilan ini dilihat berdasarkan pada hasil yang diperoleh pada siklus 1 dan siklus 2 dalam bentuk persentase yang telah dilaksanakan oleh para peneliti sebelumnya.

Jadi peneliti menyarankan kepada pembaca terutama guru khususnya guru di sekolah dasar agar mempertimbangkan model TPS ini untuk diterapkan dalam pembelajaran berbasis kelompok. Kelompokkelompok yang biasanya dibentuk oleh guru dalam pembelajaran beranggotakan 5-8 orang. Sedangkan untuk model ini anggota kelompok hanya 2 orang atau disebut berpasangan. Dengan demikian guru mudah mengontrol pembelajaran dan memberikan sedikit kesempatan untuk peserta didik ribut dan bermain karena satu kelompok hanya terdiri dari 2 orang sehingga dapat mencapai tujuan pembelajaran dengan tepat dan cepat.

\section{DAFTAR PUSTAKA}

Alfahmi, A. M. (2014). Penrapan Model Pembelajaran Kooperatif Tipe Tps (Think Pair Share) Untuk Meningkatkan Hasil Belajar Siswa Pada Mata Pelajaran IPS Di Sekolah Dasar. Jurnal Penelitian 
Pendidikan Guru Sekolah Dasar, 2(2), 1-11.

AM, I. A., Saputra, S. Y., \& Amelia, D. J. (2018). Pembelajaran tematik integratif pada kurikulum $2013 \mathrm{di}$ kelas rendah SD Muhammadiyah

Wajak. JINoP (Jurnal Inovasi Pembelajaran), 4(1), 35-46.a

Dania, R., \& Sukma, E. (2020). Peningkatan Proses

Pembelajaran Tematik Terpadu Menggunakan Model Cooperative Learning Tipe Think Pair Share di Sekolah Dasar. Jurnal Pendidikan Tambusai, 4(3), 2624-2636.

Desyandri, D. (2017, December). Internalization of Local Wisdom Values through Music Art as Stimulation of Strengthening Character Education in Early Childhood Education; A Hermeneutic Analysis and Ethnography Studies. In International Conference of Early Childhood Education (ICECE 2017) (pp. 13-16). Atlantis Press.

Fahrullisa, R., Putra, F. G., \& Supriadi, N. (2018). Pengaruh Model
Pembelajaran Kooperatif Tipe

Think Pair Share

(TPS)

berbantuan Pendekatan

Investigasi terhadap

Kemampuan Komunikasi

Matematis. NUMERICAL: Jurnal Matematika dan Pendidikan Matematika, 79-86.

Fitria, Y., Hasanah, F. N., \& Gistituati, N. (2018). Critical Thinking Skills of Prospective Elementary School Teachers in Integrated Science-Mathematics

Lectures. Journal of Education and Learning (EduLearn), 12(4), 597-603.

Handayani, R. D., \& Yanti, Y. (2017). Pengaruh Model Pembelajaran Kooperatif Tipe Think Pair Share terhadap Hasil Belajar PKn Siswa di Kelas IV MI Terpadu Muhammadiyah Sukarame Bandar Lampung. TERAMPIL: Jurnal Pendidikan dan Pembelajaran Dasar, 4(2), 107123.

Indriani, D. S. (2014). Keefektifan model think pair share terhadap aktivitas dan hasil belajar IPS. Journal of Elementary Education, 3(2), 21-27. 
Indriyani, D., Desyandri, D., Fitria, Y., \& Irdamurni, I. (2019). Perbedaan Model Children's Laerning in Csinece (CLIS) dan Model Scinetific terhadap Hasil Belajar Siswa pada Pembelajaran Tematik Terpadu di Kelas IV SD. Jurnal Basicedu: Research dan Learning in Elemnetary Education, 3(2), 627-633.

Irwan, V. P., \& Mansurdin, M. (2020). Penerapan Model Problem Based Learning Dalam Peningkatan Hasil Belajar Tematik Terpadu Di Sekolah Dasar. Jurnal Pendidikan Tambusai, 4(3), 2097-2107.

Jannah, N. H., \& Mudjiran, M. (2019). MODEL PEMBELAJARAN KOOPERATIF TIPE THINK PAIR SHARE, AKTIVITAS DAN HASIL BELAJAR PESERTA DIDIK. Jurnal Basicedu, 3(4), 2125-29.

Julaeha, S. (2019). Problematika Kurikulum Dan Pembelajaran Pendidikan Karakter. Jurnal Penelitian Pendidikan Islam,[SL], 7(2), 157-182.
Kusuma, F. W., \& Aisyah, M. N. (2012). Implementasi Model Pembelajaran Kooperatif Tipe think pair share untuk meningkatkan aktivitas belajar akuntansi siswa kelas XI IPS 1 SMA Negeri 2 Wonosari tahun ajaran 2011/2012. Jurnal Pendidikan Akuntansi Indonesia, 10(2).

Kusmana, S. (2017). Pengembangan literasi dalam kurikulum pendidikan dasar dan menengah. Diglosia: Jurnal Pendidikan, Kebahasaan, dan Kesusastraan Indonesia, 1(1).

Lestari, A. P. (2013). Peningkatan Motivasi Belajar Siswa Dengan Penerapan Model Pembelajaran Kooperatif Tipe TPS (Think Pair Share) dalam Pembelajaran IPS Kelas IV Sekolah Dasar. Jurnal Penelitian Pendidikan Guru Sekolah Dasar, 1(2), 1-9.

Lubis, A. B., Miaz, Y., Taufina, T., \& Desyandri, D. (2019). PENGARUH MODEL EVERYONE IS A TEACHER HERE TERHADAP AKTIVITAS DAN HASIL BELAJAR IPS 
SISWA

SD. Jurnal

Basicedu, 3(2), 725-735.

Marta, R. (2017). Peningkatan Hasil Belajar Matematika Dengan Model Kooperatif Tipe Think Pair Share Di Sekolah Dasar. Jurnal Cendekia: Jurnal Pendidikan Matematika, 1(2), 74-79.

Meiharty, F. (2018). Penerapan Model Pembelajaran Kooperatif Tipe Think Pair Share untuk Memperbaiki Proses Pembelajaran dan Meningkatkan Hasil Belajar IPS Siswa Kelas V SD Negeri 21 Balai Makam Kecamatan Mandau. Primary: Jurnal Pendidikan Guru Sekolah Dasar, 7(2), 312-320.

Noor, N., \& Munandar, I. (2019). Pengaruh Model Pembelajaran Kooperatif (Tipe TAI dan TPS) dan Aktivitas Belajar terhadap Hasil Belajar Matematika: Eksperimen Pada Kelas X SMK Kosgoro Karawang. Jurnal IImu Pendidikan (JIP) STKIP Kusuma Negara, 11(1), 65-75.
Novita, R. (2014). Efektivitas Model Pembelajaran Kooperatif Tipe Think Pair Share (TPS) Pada Materi Trigonometri Di Kelas XI IA1 SMA Negeri 8 Banda Aceh. Visipena, 5(1), 128-135.

Popiyanto, Y. (2020). Kooperatif Tipe Think Pair Share terhadap Hasil Belajar Tematik Siswa Sekolah Dasar. Trapsila: Jurnal Pendidikan Dasar, 1(01), 44-54.

Priatna, A., \& Patmawati, I. (2021). PENGARUH MODEL PEMBELAJARAN KOOPERATIF TIPE TWO STAY TWO STRAY TERHADAP PENINGKATAN KETERAMPILAN MENYIMAK PESERTA DIDIK PADA MATA PELAJARAN BAHASA INDONESIA. Pendas: Jurnal IImiah Pendidikan Dasar, 5(2), 187-203.

Purnomo, A. (2013). Peningkatan Kemampuan Berpikir Kritis Siswa dengan Penerapan Model Pembelajaran Kooperatif Tipe TPS (THINK PAIR SHARE) Dalam Pembelajaran IPS di Sekolah Dasar. Jurnal Penelitian Pendidikan Guru Sekolah Dasar, 1(2), 1-9.

Puspitasari, E., Setyosari, P., \& Amirudin, A. (2016).

Peningkatan motivasi dan hasil 
belajar melalui think pair share (tps) di sekolah dasar. Jurnal Pendidikan: Teori, Penelitian, Dan Pengembangan, 1(7), 1432-1436.

Rahayu, T. R., Huda, M., \& Shodikin, A. (2017). Pengaruh Model Pembelajaran Kooperatif Tipe TPS dengan Alat Peraga Rubbik terhadap Self Efficacy Siswa pada Materi Kubus dan Balok. Inspiramatika, 3(2), 117123.

Reinita, R., \& Andriska, D. (2017). Pengaruh Pengunaan Model Kooperatif Tipe Think Pair Share (TPS) dalam Pembelajaran PKn di Sekolah Dasar. Jurnal Inovasi Pendidikan Dan Pembelajaran Sekolah Dasar, 1(2), 61-73.

Salsabila, R., Murtono, M., \& Purbasari, I. (2020). ANALISIS PROSES DAN DAMPAK PEMBELAJARAN DARING DI SD AL-ISLAM PENGKOL JEPARA PADA MASA PANDEMI COVID-19 TAHUN 2020. Pendas: Jurnal IImiah Pendidikan Dasar, 5(2), 151159.
Sugiarto, D., \& Sumarsono, P. (2014).

The implementation of think-pairshare model to improve students' ability in reading narrative texts. International Journal of English and Education, 3(3), 206-215.

Surayya, L., Subagia, I. W., \& Tika, I. N. (2014). Pengaruh model pembelajaran think pair share terhadap hasil belajar IPA ditinjau dari keterampilan berpikir kritis siswa. Jurnal Pendidikan dan Pembelajaran IPA Indonesia, 4(1).

Tembang, Y., Sulton, S., \& Suharjo, S. (2017). Peningkatan motivasi dan hasil belajar melalui model pembelajaran think pair share berbantuan media gambar di sekolah dasar. Jurnal Pendidikan: Teori, Penelitian, dan Pengembangan, 2(6), 812817.

Setiadi, H. (2016). Pelaksanaan penilaian pada Kurikulum 2013. Jurnal Penelitian dan Evaluasi Pendidikan, 20(2), 166178.

Sinambela, P. N. (2017). Kurikulum 2013 dan implementasinya 
dalam pembelajaran. Generasi

Kampus, 6(2).

Triayomi, R., \& Larassandi, A. M.

(2021). ANALISIS

PELAKSANAAN KURIKULUM

2013 KELAS VI DI SDK

FRATER XAVERIUS 2

PALEMBANG. Pendas: Jurnal

Ilmiah Pendidikan Dasar, 5(2),

168-175. 